\title{
The Effects of Silicon on Festuca Arundinacea under PH Stress
}

\author{
Yuchen Wang ${ }^{1, \mathrm{a}}$, Siliang Shao ${ }^{1, \mathrm{~b}}$ and Shuming Ju ${ }^{1,2, \mathrm{c*}}$ \\ 1Schoolof Environment, Xuzhou Institute of Technology, No.2, Lishui Road, Xuzhou Jiangsu 221116, China. \\ 2Jiangsu Laboratory of Pollution Control and Resource Reuse, No.2, Lishui Road, Xuzhou Jiangsu 221116, \\ China. \\ a617607306@qq.com, ${ }^{b} 1079147455 @ q q . c o m,{ }^{c}$ qusm2010@163.com
}

\author{
Keywords: Festuca arundinacea; Exogenous silicon; PH stress; Growth; Antioxidant enzyme activity
}

\begin{abstract}
Experiments were performed to study effects of exogenous silicon $(0,2$, and $8 \mathrm{mM})$ and $\mathrm{pH}$ stress $(\mathrm{pH} 3.0,5.5,8.0)$ on Festuca arundinacea. The effect on growth, photosynthetic pigments content and antioxidant enzymes activities were researched. Our results indicated that under $\mathrm{pH} 3.0$ stress, above ground dry weight, the activities of catalase (CAT), peroxidase (POD) and chlorophyll content were maximum under the $2 \mathrm{mM}$ Si treatment and restrained under $8 \mathrm{mM}$ Si treatment. Under pH8.0 treatment, the plant height, the activities of APX, POD and chlorophyll content increased significantly with increase of the concentration of silicon treatment which were maximum under $8 \mathrm{mM}$ Si treatment, but the POD, dry weights of roots and above ground declined a little compared to $2 \mathrm{mM}$ Si treatment. It illustrates that under acid stress, the lower concentration of Si treatment is effective in alleviating the injury of plants under acid and alkali stress.
\end{abstract}

\section{Introduction}

$\mathrm{pH}$ stress is considered one of the most detrimental environmental stresses in light of the intensified acid rain and salinization. Acid rain as a global environmental issue can cause soil acidification and inhibit the growth of plants[1.2]. Excessive alkaline salt concentrations can damage or even kill plants by generating osmotic, ionic, and oxidative stress[3]. Many studies has investigated the injuries effect and forms of the plants [4,5]. Tall fescue (Festuca arundinacea cv. Barlexas) is a major species of cool-season forages and turf grasses. They are widely used in warm temperate to subtropical regions all over the world because they are easy to plant [6]. but its persistence is impaired by biotic and abiotic stresses [7].

Silicon $(\mathrm{Si})$ is the second most abundant element after oxygen in soil. Si plays an important role in biological process, primarily it provides mechanical strength and elasticity to cell walls [8]. Si mainly in the form of silicic acid, $\mathrm{H}_{4} \mathrm{SiO}_{4}$, is prominent in the soil solution [9]. Several beneficial effects of $\mathrm{Si}$ have been reported, including increased photosynthetic activity, insect and disease resistance, reduced mineral toxicity, improved nutrient imbalance, and enhanced drought and frost tolerance [10-14]. But researches showed different expression patterns and tissue or cellular localization that are associated with different levels of $\mathrm{Si}$ accumulation in different plant species [15]. Currently, N, P as the main nutrition applied in the lawn. Impacts from unremittingly elevated $\mathrm{N}, \mathrm{P}$ pollution rates can extend beyond the directly affected plant-soil systems, and impinge on ecosystem services such as provision of clean drinking water [16]. Therefor, it is vital to find an environmental-friendly fertilizer to substitute $\mathrm{N}$ and $\mathrm{P}$ partly. $\mathrm{Si}$ is one of the elements will not damage soil with excessive extension[17]. The previous experiment showed that especially the plants may be able to substitute carbon compounds in a relevant share by silicon compounds[18]. Investigating the effect of $\mathrm{Si}$ in Festuca arundinacea under different $\mathrm{pH}$ treatment will provide basis for the $\mathrm{Si}$ application in the grass planting.

\section{Materials and Methods}

Plant Materials and Treatments. The Festuca arundinacea seeds were sterilized for 20 min with $0.5 \%$ (w/v) permanganate solution, rinsed three times with sterile distilled water, then soaked in $\mathrm{Na}_{2} \mathrm{SiO}_{3} \cdot 9 \mathrm{H}_{2} \mathrm{O}_{2}$ solution for $24 \mathrm{~h}$ at $25^{\circ} \mathrm{C}$. The seeds were planted in the plastic pots filled with perlite. Three treatments of $\mathrm{pH}$ values $(\mathrm{pH} 3.0,5.5,8.0)$ and three concentrations of $\mathrm{Si}(0,2,8 \mathrm{mM})$ were selected in the present work. There were nine treatment and every treatment repeated three times. $\mathrm{Na}_{2} \mathrm{SiO}_{3} \cdot 9 \mathrm{H}_{2} \mathrm{O}_{2}$ was used as donor of Si. Tap water used to prepare different $\mathrm{Si}$ concentration of solution, then $\mathrm{H} 2 \mathrm{SO} 4$ ) and $\mathrm{NaOH}$ were used to adjust $\mathrm{pH}$ value of solution using the PHS-3C type $\mathrm{pH}$ instrument. The solution was added in order to keep the perlite moist with at fixed time and with fixed quantity everyday. 30-days-seedlings were harvested to determine data.

Determination of Growth. Plant height were measured before drying. Plant materials dried at $105{ }^{\circ} \mathrm{C}$ for $30 \mathrm{~min}$ and then $80^{\circ} \mathrm{C}$ to constant weight in oven were used to measure dry weight [5].

Determination of Antioxidant Enzymes Activities. Approximately $0.20 \mathrm{~g}$ of fresh leaves was extracted in 
$50 \mathrm{mM}$ potassium phosphate buffer (PBS, $\mathrm{pH} 7.8$ ). The homogenates were centrifuged at $15,000 \times \mathrm{g}$ and $4^{\circ} \mathrm{C}$ for $20 \mathrm{~min}$, and the supernatants were used for assaying enzyme activity[19].

CAT (EC 1.11.1.6) activity was measured by determining the decrease in the absorbance at $240 \mathrm{~nm}$ due to $\mathrm{H}_{2} \mathrm{O}_{2}$ consumption, as described by Azevedo et al[20]. The reaction mixture contained $0.3 \mathrm{ml}$ of $\mathrm{H}_{2} \mathrm{O}_{2}(0.1 \mathrm{M})$, $1.5 \mathrm{ml}$ of PBS (50 mM pH 7.8), $0.2 \mathrm{ml}$ of the sample and $1 \mathrm{ml}$ of distilled water.

POD (EC 1.11.1.7) activity was determined according to Bai et al[21]. with some modifications. The reaction mixture contained $1.0 \mathrm{ml}$ of $0.3 \% \mathrm{H}_{2} \mathrm{O}_{2}, 1.0 \mathrm{ml}$ of $0.05 \mathrm{M} \mathrm{PBS}(\mathrm{pH} 7.8), 0.8 \mathrm{ml}$ of $0.2 \%$ guaiacol, and $0.2 \mathrm{ml}$ of the sample. The increase in absorbance at $470 \mathrm{~nm}$ during a $1 \mathrm{~min}$ period was determined.

AXP (EC 1.11.1.11) activity was determined by measuring the decrease in the absorbance of ascorbic acid (ASA) at $290 \mathrm{~nm}[22]$. The reaction mixture contained $2.7 \mathrm{ml}$ of a mixture containing PBS $(25 \mathrm{mM}, \mathrm{pH} 7.0)$ $0.1 \mathrm{~mL}$ AsA $(7.5 \mathrm{mM}), 0.1 \mathrm{ml}$ of the sample, and $0.1 \mathrm{ml}$ of $\mathrm{H}_{2} \mathrm{O}_{2}(300 \mathrm{mM})$. The oxidation of ascorbate was initiated by $\mathrm{H}_{2} \mathrm{O}_{2}$ and was monitored for $3 \mathrm{~min}$. One unit of APX activity was defined as the amount of enzyme oxidizing $1 \mu \mathrm{M}$ of ascorbate, and the extinction coefficient was $2.8 \mathrm{mM}^{-1} \mathrm{~cm}^{-1}$.

Determination of Malondialdehyde (MDA). The thiobarbituric acid (TBA) test was used to determine MDA content for the measurement of membrane damage[23]. Plant samples $(0.3 \mathrm{~g})$ were homogenized in $2 \mathrm{ml}$ cold phosphate buffer ( $\mathrm{pH} 7.8,50 \mathrm{mM}$ ), and then the solution was homogenized in $3 \mathrm{ml}$ of $0.5 \%$ TBA in 5\% trichloroacetic acid (w/v). Samples were heated at $100^{\circ} \mathrm{C}$ for $10 \mathrm{~min}$, and quickly cooling, the homogenate was centrifuged at $4500 \times \mathrm{g}$ for $10 \mathrm{~min}$ again. The absorbance was measured at 440, 532 and $600 \mathrm{~nm}$, distilled water being used as a blank control. The concentration of MDA was calculated using the extinction coefficient of $155 \mathrm{mM}^{-1} \mathrm{~cm}^{-1}$ and by correcting the specific absorbance at $600 \mathrm{~nm}$ of wavelength.

Determination of Photosynthetic Pigments Content. Photosynthetic pigments were extracted using ethanol-acetone solution (v/v 1:2). The absorbance were read at $663 \mathrm{~nm}, 645 \mathrm{~nm}$ and $470 \mathrm{~nm}$ respectively. The content of total chlorophyll, chlorophyll a, chlorophyll b and carotenoid were calculated by using the formula described by Lichtenthaler [24].

Statistical Analysis. Data were analysed using of Student's t-test (Spss 19.0) and analysis of variance (ANOVA) and comparisons between the mean values were made by the least significant difference (LSD) test at $\mathrm{p}<0.05$, and a standard error (SE) was calculated.

\section{Result}

Effects of Si on the Growth of Festuca Arundinacea under Ph Stress. For pH8.0-treatment, the plant height significantly increased with the increase of Si concentration, but for $\mathrm{pH}$ 3.0-treatment, the plant height showed lower increase (Table1). The plant height firstly increased and then decreased with the increase of $\mathrm{Si}$ concentration under the condition of pH5.5-treatment. When the Festuca arundinacea seedlings were treated with $\mathrm{Si}$ and $\mathrm{pH} 3.0$ (or 8.0), the height augmented insignificantly compared with the plants were treated with the $\mathrm{pH}$ 5.5- treatment.

The acid stress and alkali stress affected dry weight (DW) of roots, stems and leaves insignificantly (Table 1). Under all $\mathrm{pH}$ treatment, the DW of above ground showed the tendency which increased first and then decreased with the increase of Si concentration and increased significantly in a moderate concentration of Si $(2 \mathrm{mM})(\mathrm{P}<0.05)$. The DW of above ground increased $54.2 \%$ under $\mathrm{pH} 3.0$ treatment, $48.7 \%$ under $\mathrm{pH} 5.5$ treatment and $10.24 \%$ under $\mathrm{pH} 8.0$ treatment compared with those of the corresponding single treatments with $\mathrm{pH}$ (Table 1). Si interacting with $\mathrm{pH} 3.0$ (or 8.0) treatment has augmented plant height significantly compared with the plants were treated with the single $\mathrm{pH}$ 5.5.

When the plants were treated $\mathrm{pH} 3.0$, the $\mathrm{DW}$ of roots decreased with addition of $\mathrm{Si}$, but the diversity was not significant $(\mathrm{P}<0.05)$. When the plants were treated with $\mathrm{pH} 5.5$ (or 8.0), the $\mathrm{DW}$ of roots showed the tendency which increased first and then decreased with the increase of Si concentration, but the diversity was not significant. The result shows supplying $\mathrm{Si}$ affects insignificantly to the DW of roots, but is significantly positive with the DW of above ground.

Table 1 Effects of Si on the growth of Festuca arundinacea under $\mathrm{pH}$ stress

\begin{tabular}{ccccc}
\hline $\mathrm{pH}$ & $\mathrm{Si}(\mathrm{mM})$ & Plant height $[\mathrm{cm}]$ & Root dry weight [g/5stock] & Above ground dry weight [g/5stock] \\
\hline 3.0 & 0 & $4.766 \pm 0.428 \mathrm{~b}$ & $0.0107 \pm 0.0047 \mathrm{ab}$ & $0.0110 \pm 0.0032 \mathrm{c}$ \\
& 2 & $4.923 \pm 0.574 \mathrm{~b}$ & $0.0100 \pm 0.0015 \mathrm{~b}$ & $0.0170 \pm 0.0021 \mathrm{a}$ \\
& 8 & $4.944 \pm 0.500 \mathrm{~b}$ & $0.0078 \pm 0.0014 \mathrm{~b}$ & $0.0154 \pm 0.0011 \mathrm{ab}$ \\
5.5 & 0 & $5.061 \pm 0.489 \mathrm{ab}$ & $0.0109 \pm 0.0015 \mathrm{ab}$ & $0.0093 \pm 0.0016 \mathrm{c}$ \\
& 2 & $5.601 \pm 0.962 \mathrm{a}$ & $0.0142 \pm 0.0338 \mathrm{a}$ & $0.0139 \pm 0.0014 \mathrm{~b}$ \\
& 8 & $5.473 \pm 0.732 \mathrm{ab}$ & $0.0124 \pm 0.0033 \mathrm{ab}$ & $0.0108 \pm 0.0019 \mathrm{c}$ \\
8.0 & 0 & $4.359 \pm 0.537 \mathrm{~b}$ & $0.0137 \pm 0.0017 \mathrm{ab}$ & $0.0117 \pm 0.0024 \mathrm{bc}$ \\
& 2 & $4.904 \pm 0.297 \mathrm{~b}$ & $0.0140 \pm 0.0247 \mathrm{a}$ & $0.0129 \pm 0.0010 \mathrm{bc}$ \\
& 8 & $5.140 \pm 0.441 \mathrm{ab}$ & $0.0136 \pm 0.0043 \mathrm{ab}$ & $0.0113 \pm 0.0018 \mathrm{c}$ \\
\hline
\end{tabular}

Significant differences at $\mathrm{p}<0.05$ were showed with different letters in the same line 
Effects of Si on the Antioxidant Enzymes Activities of Festuca Arundinacea under ph Stress. When Si was not applied, the POD, CAT and APX activities in leaves of tall fescue treated with $\mathrm{pH} 5.5$ solutions were the hightest than the $\mathrm{pH} 3.0$ or 8.0 treatments. and for $\mathrm{pH} 8.0$-treatment, the POD, CAT and APX activities was lowest. Under $\mathrm{pH} 3.0$ stress, POD activities declined with the increase of Si concentration, but the difference is not significant $(\mathrm{P}<0.05)$. for $\mathrm{pH} 5.5$-treatment, $\mathrm{POD}$ activities in $\mathrm{Si} 2$ concentration were maximum and caused negative impact with Si8 concentration. Under pH8.0 stress, POD activities significantly improved with the increase of Si concentration (Figure 1).

When $\mathrm{Si}$ was not applied, CAT activities were significantly restrained with $\mathrm{pH} 3.0$ (or 8.0) treatment compared with $\mathrm{pH} 5.5$ treatment (Figure 2). Under the same $\mathrm{pH}$ value condition, the CAT activities increased first and then decreased with the increase of $\mathrm{Si}$ concentration. for $\mathrm{pH} 5.5$-treatment, the CAT activities increased $24.7 \%$ and under pH8.0 treatment increased by $11.3 \%$, but under $\mathrm{pH} 3.0$ treatment barely increased $1.3 \%$ compared with those of the control and the corresponding single treatments of $\mathrm{pH}$. When the combined treatment of $2 \mathrm{mM} \mathrm{Si}$ and $\mathrm{pH} 3.0$ (or 5.5) was used caused negative impact. The $\mathrm{pH} 3.0$ treatment decreased $15.5 \%$ and $\mathrm{pH} 5.5$ treatment decreased $2.3 \%$ (Figure 2). Si interacting with $\mathrm{pH} 8.0$ treatment has significantly enhanced CAT activities.

When $\mathrm{Si}$ was not applied, APX activities were insignificantly restrained under $\mathrm{pH} 3.0$ (or 8.0) stress $(\mathrm{P}<0.05)$. Under pH3.0 stress, APX activities enhanced in $2 \mathrm{mM}$ Si treatment and restrained in $8 \mathrm{mM} \mathrm{Si}$ treatment, but the diversity was not significant. under pH5.5 treatment, APX activities improved 21.9\% significantly in $\mathrm{Si} 2$ concentration and the APX activities in $8 \mathrm{mM} \mathrm{Si}$ treatment were less than in $2 \mathrm{mM}$ Sitreatment(Figure 3). It illustrates it will cause negative impact with the increase of Si concentration. The APX activities improved when the combined treatment of $2 \mathrm{mM}(8 \mathrm{mM}) \mathrm{Si}$ and $\mathrm{pH} 8.0$ was used and in $8 \mathrm{mM}$ Si treatment significantly improved $10.1 \%$ compared with those of the control and the corresponding single treatments of $\mathrm{pH}$. The result indicate $\mathrm{Si}$ interacting with $\mathrm{pH} 3.0$ (or 8.0) treatment can enhance APX activities, but it is not significant with $\mathrm{pH} 3.0$ treatment.

Effects of Si on the MDA Content of Festuca Arundinacea under pH stress. When Si was not applied, MDA levels were significantly improved under $\mathrm{pH} 3.0$ stress, but reduced under $\mathrm{pH} 8.0$ stress. for $\mathrm{pH}$ 3.0-treatment, the application of Si significantly reduced MDA content which decreased by $11.0 \%$ in $2 \mathrm{mM} \mathrm{Si}$ treatment and $20.6 \%$ in $8 \mathrm{mM}$ Si treatment(Table 2). Under pH5.5 treatment, the application of Si also reduced MDA content , but it was not significant $(\mathrm{P}<0.05)$, which decreased by $2.6 \%$ in $\mathrm{Si} 2$ concentration and $10.5 \%$ in Si8 concentration. However, Under pH8.0 treatment, the MDA level significantly increased in $2 \mathrm{mM} \mathrm{Si}$ treatment and $8 \mathrm{mM}$ Si treatment compared with the single $\mathrm{pH}$ treatment and it was approximate in $2 \mathrm{mM} \mathrm{Si}$ treatmentand $8 \mathrm{mM}$ Si treatment. Si interacting with pH3.0 treatment significantly decreased MDA content.

Table 2 Effects of Si on POD, CAT, APX activity and MDA content in Festuca arundinacea leaves under pH stress

\begin{tabular}{cccccc}
\hline $\mathrm{pH}$ & $\mathrm{Si}[\mathrm{mM}]$ & $\mathrm{POD}[\mathrm{mmol} / \mathrm{L}]$ & $\mathrm{CAT}[\mathrm{mmol} / \mathrm{L}]$ & APX $[\mathrm{mmol} / \mathrm{L}]$ & $\mathrm{MDA}[\mathrm{nmol} / \mathrm{g}(\mathrm{FW})]$ \\
\hline 3.0 & 0 & $36.285 \pm 0.711 \mathrm{~b}$ & $440.925 \pm 2.205 \mathrm{~d}$ & $56.961 \pm 0.822 \mathrm{c}$ & $43.273 \pm 1.522 \mathrm{a}$ \\
& 2 & $34.736 \pm 1.073 \mathrm{c}$ & $447.607 \pm 8.076 \mathrm{~cd}$ & $57.913 \pm 0.602 \mathrm{c}$ & $38.855 \pm 0.984 \mathrm{~b}$ \\
5.5 & 8 & $31.816 \pm 0.627 \mathrm{~d}$ & $371.694 \pm 3.713 \mathrm{f}$ & $56.072 \pm 1.321 \mathrm{c}$ & $34.367 \pm 0.671 \mathrm{c}$ \\
& 0 & $36.523 \pm 0.757 \mathrm{~b}$ & $454.677 \pm 3.984 \mathrm{c}$ & $57.153 \pm 0.602 \mathrm{c}$ & $34.561 \pm 1.341 \mathrm{c}$ \\
& 2 & $39.212 \pm 1.044 \mathrm{a}$ & $567.032 \pm 7.878 \mathrm{a}$ & $68.561 \pm 1.746 \mathrm{a}$ & $33.669 \pm 1.218 \mathrm{c}$ \\
8.0 & 8 & $26.110 \pm 0.525 \mathrm{ef}$ & $444.169 \pm 1.241 \mathrm{~d}$ & $60.637 \pm 1.729 \mathrm{~b}$ & $30.931 \pm 0.322 \mathrm{~d}$ \\
& 0 & $25.835 \pm 0.958 \mathrm{f}$ & $421.393 \pm 3.254 \mathrm{e}$ & $56.167 \pm 1.528 \mathrm{c}$ & $29.558 \pm 1.342 \mathrm{~d}$ \\
& 2 & $27.493 \pm 0.894 \mathrm{e}$ & $468.826 \pm 4.408 \mathrm{~b}$ & $57.729 \pm 0.775 \mathrm{c}$ & $34.555 \pm 0.743 \mathrm{c}$ \\
\hline
\end{tabular}

Significant differences at $\mathrm{p}<0.05$ were showed with different letters in the same line

Effects of Si on the Photosynthetic Pigments Content of Festuca Arundinacea under pH stress. The Chl content and carotenoid contents decreased significantly under single pH3.0 (or 8.0) treatment compared with $\mathrm{pH} 5.5$ treatment, especially under $\mathrm{pH} 3.0$ treatment $(\mathrm{p}<0.05)$. For $\mathrm{pH} 3.0$-treatment, The $\mathrm{Chl} \mathrm{b}, \mathrm{Chl}$ a, total $\mathrm{Chl}$ and carotenoid contents increased significantly with the addition of $\mathrm{Si}$, at the same time, the Chl a content in $8 \mathrm{mM}$ Si treatment was less than in $2 \mathrm{mM}$ Si treatment. The Chl a content increased by $50.4 \%$ in $2 \mathrm{mM} \mathrm{Si}$ treatment and $48.7 \%$ in $8 \mathrm{mM}$ Si treatment compared with single pH3.0 treatment (Table 3). It showed the increase of Si concentration caused negative impact. for $\mathrm{pH} 5.5$-treatment, the $\mathrm{Chl}$ and carotenoid content in $2 \mathrm{mM}$ Si treatment was less than the single pH5.5 treatment and in $8 \mathrm{mM}$ Si treatment raised a little than it in $2 \mathrm{mM}$ Si treatment.Under pH8.0 treatment, the $\mathrm{Chl}$ and carotenoid content in $2 \mathrm{mM}$ Si treatment was also less than it in single pH8.0 treatment, but it in $8 \mathrm{mM}$ Si treatment was more than it in single pH8.0 treatment. The $\mathrm{Chl}$ a content increased by $14.8 \%$ in $8 \mathrm{mM} \mathrm{Si}$ treatment compared with the single pH8.0 treatment. 
Table 3 Effects of Si on photosynthetic pigments content of Festuca arundinacea under $\mathrm{pH}$ stress

\begin{tabular}{cccccc}
\hline $\mathrm{pH}$ & $\mathrm{Si}[\mathrm{mM}]$ & Chla $[\mathrm{mg} / \mathrm{g}]$ & $\mathrm{Chl} \mathrm{b}[\mathrm{mg} / \mathrm{g}]$ & Total Chl $[\mathrm{mg} / \mathrm{g}]$ & Carotenoid $[\mathrm{mg} / \mathrm{g}]$ \\
\hline 3.0 & 0 & $1.176 \pm 0.005 \mathrm{~g}$ & $0.559 \pm 0.005 \mathrm{c}$ & $1.735 \pm 0.010 \mathrm{f}$ & $0.4824 \pm 0.009 \mathrm{~g}$ \\
& 2 & $1.760 \pm 0.003 \mathrm{a}$ & $0.693 \pm 0.002 \mathrm{a}$ & $2.453 \pm 0.005 \mathrm{a}$ & $0.670 \pm 0.004 \mathrm{~b}$ \\
& 8 & $1.748 \pm 0.011 \mathrm{~b}$ & $0.705 \pm 0.009 \mathrm{a}$ & $2.453 \pm 0.019 \mathrm{a}$ & $0.686 \pm 0.005 \mathrm{a}$ \\
5.5 & 0 & $1.703 \pm 0.003 \mathrm{c}$ & $0.692 \pm 0.003 \mathrm{a}$ & $2.395 \pm 0.006 \mathrm{~b}$ & $0.644 \pm 0.005 \mathrm{c}$ \\
& 2 & $1.495 \pm 0.004 \mathrm{e}$ & $0.629 \pm 0.003 \mathrm{a}$ & $2.125 \pm 0.005 \mathrm{~cd}$ & $0.591 \pm 0.005 \mathrm{~d}$ \\
& 8 & $1.509 \pm 0.001 \mathrm{~d}$ & $0.627 \pm 0.007 \mathrm{~b}$ & $2.136 \pm 0.007 \mathrm{c}$ & $0.596 \pm 0.004 \mathrm{~d}$ \\
8.0 & 0 & $1.485 \pm 0.006 \mathrm{e}$ & $0.617 \pm 0.007 \mathrm{~b}$ & $2.102 \pm 0.024 \mathrm{~d}$ & $0.575 \pm 0.009 \mathrm{e}$ \\
& 2 & $1.373 \pm 0.014 \mathrm{f}$ & $0.617 \pm 0.018 \mathrm{~b}$ & $1.943 \pm 0.028 \mathrm{e}$ & $0.544 \pm 0.005 \mathrm{f}$ \\
& 8 & $1.705 \pm 0.004 \mathrm{c}$ & $0.692 \pm 0.001 \mathrm{a}$ & $2.396 \pm 0.005 \mathrm{~b}$ & $0.668 \pm 0.004 \mathrm{~b}$ \\
\hline
\end{tabular}

Significant differences at $\mathrm{p}<0.05$ were showed with different letters in the same line

\section{Discussion}

The various physiological parameters of Festuca arundinacea have diversities in different $\mathrm{pH}$ treatments, but it has less effect under acid treatment than alkali treatment with stronger acid resistance. The application of Si alleviates the harm of plants under $\mathrm{pH}$ stress and the effect of $\mathrm{Si}$ in Festuca arundinacea has much difference under different $\mathrm{pH}$ stress.

The result shows under pH3.0 treatment, DW of above ground, the activities of CAT, APX and Chl Content were maximum under the $2 \mathrm{mM}$ Si treatment and will be restrained under $8 \mathrm{mM}$ Si treatment. The increase of DW of above ground, Chl content, carotenoid content and the decrease of MDA content was extremely significant. Chl and carotenoid are the principal pigment for photosynthesis in green plants. Their content can provide valuable information on physiological state of plants. Analysis of chlorophyll a fluorescence parameters is considered as an important approach for evaluating the health or integrity of the internal apparatus during photosynthetic process within a leaf and provides a rapid and accurate technique for detecting and quantifying the tolerance of plants to stress[25]. The application of Si could increase the antioxidant enzymes activities and decrease MDA contention. The POD, CAT and APX, as antioxidant anzymes, could eliminate hydrogen peroxide and reduce the toxicity, while the increase of the reactive oxygen species cause the lipid peroxidation[26]. MDA is a product of the peroxidation of unsaturated fatty acids in phospholipids. The change of MDA content has been widely used as an indicator of free radical damage to cell membranes[27]. The induced decrease of MDA content indicated Si application improved the Festuca arundinacea resistance. The POD activities and DW of roots decreased may caused by the too high Si concentration. Si distributed unevenly throughout the organ in different plants, some plants the $\mathrm{Si}$ concentration over ground is more than in the roots as rice [28]. But some plants the Si concentration over ground is far less than in the roots as the Trifolium incarnatum, the Si concentration in the roots is approximately eight times more than $\mathrm{Si}$ over ground. Festuca arundinacea belonging to grasses shows $\mathrm{Si}$ concentration underground is more than over ground. The Si Festuca arundinacea absorbed mostly accumulate in the roots, so the Si concentration over ground is lower and under ground is higher to cause the inhabited impact. It is unable to take up Si actively via the roots, even though the concentration in soil solution is high, and, therefore, fail to accumulate high Si in the tops and to benefit from Si. So, with low Si uptake, foliar application has been attempted [29].

Under pH5.5 treatment, the plant height, DW of roots, DW of stems and leaves, the activities of APX, POD, CAT were all maximums in $2 \mathrm{mM}$ Si treatment, but the chl and carotenoid contention decreased in $2 \mathrm{mM} \mathrm{Si}$ treatment. Previous experiences illustrated Si did not have effects in the plants chl under the normal growth condition, barely had protective effect in the plants chl under stress[30].

Under pH8.0 treatment, the plant height, the activities of APX, POD, Chl and carotenoid content increased significantly with increase of the concentration of silicon treatment which were maximum under $8 \mathrm{mM} \mathrm{Si}$ treatment. The study showed under pH8.0 treatment, Festuca arundinacea needed more Si to alleviate the harm by the stress, because the Festuca arundinacea suffer more harm under alkali stress possibly. The Chl content was lower in $2 \mathrm{mM} \mathrm{Si}$ treatment than in single pH8.0 treatment as former studied, the low Si concentration applied did not improve the Chl content and as the increase of Si concentration, the Chl content increased first then decreased[31]. The lower level of CAT activities in $8 \mathrm{mMSi}$ treatment than $2 \mathrm{mM}$ Si treatment is in agreement with the results of the previous experiment that showed the activity of SOD, GPX, APX, DHAR and GR in salt-stressed cucumber leaves was increased by Si addition, however, an increase in CAT activity was not observed [32].

The study illustrated that the lower concentration of Si treatment is effective in alleviating the injury of plants under acid and alkali stress. The Si fertilization can be applied in Festuca arundinacea according to the environment $\mathrm{pH}$ value to enhance its growth. 


\section{Reference}

[1] F.C. Menz and H.M. Seip, Acid rain in Europe and the United States: an update. Environ. Sci. Policy..7 (2004):253-265.

[2] T. Larssen, E. Lydersen, D.G. Tang, Y. He, J.X. Gao and H.Y. Liu, Acid rain in China. Environ. Sci. Techno. 140(2006) 418-425.

[3] C. Kütük, G. Çaycı and L. Heng, Effects of increasing salinity and N-labelled urea levels on growth, N uptake, and water use efficiency of young tomato plants. Soil Research 42(2004) 345-351.

[4] T.T. Liu, P. Wu, L.H. Wang and Q. Zhou, Response of soybean seed germination to cadmium and acid rain. Biol. Trace. Elem. Res. 144(2011)1186-1196.

[5] X. Liang, S. Fang, W. Ji \& D. Zheng,. The positive effects of silicon on rice seedlings under saline-alkali mixed stress. Communications in Soil Science and Plant Analysis. 46(2015) 2127-2138.

[6] Y. Wang, J. Zhang, J.L. Li and X.R. Ma, Exogenous hydrogen peroxide enhanced the thermotolerance of Festuca arundinacea and Lolium perenne by increasing the antioxidative capacity. Acta Physiol Plant 36(2014) 2915-2924

[7] O. Scheneiter and C. Ame 'ndola, Tiller demography in tall fescue (Festuca arundinacea) swards as in fluenced by nitrogen fertilization, sowing method and grazing management. Grass and Forage Science 67(2012) 426-436.

[8] E.Epstein. The anomaly of silicon in plant biology, Plant Physical. Proc. Natl. Acad. Sci. USA 91(1994) $11-17$

[9] L.R. Dreese, L.P. Wilding, N.E. Smeck and A.L. Senkayi, Minerals in Soil Environments, eds. Dixon, J. B. \& Weed, S. B. (Soil Sci. Soc. Am., Madison, WI) 1989: 914-974.

[10] Jian Feng Ma. Role of silicon in enhancing the resistance of plants to biotic and abiotic stresses. Soil Science and Plant Nutrition, 50(2004) 11-18.

[11] F. Chain, C. Côté-Beaulieu, F. Belzile, J. G. Menzies and R. R. Bélanger, A comprehensive transcriptomic analysis of the effect of silicon on wheat plants under control and pathogen stress conditions. The American Phytopathological Society 22(2009)1323-1330.

[12] K. Mburuab, R. Oduorb, A. Mgutub and L. Tripathia, Silicon application enhances resistance to xanthomonas wilt disease in banana. Plant Pathology. 65(2016) 807-818

[13] W. Chen, X.Yao, K, Cai and J. Chen, Silicon alleviates drought stress of rice plants by improving plant water status, photosynthesis and mineral nutrient absorption. Biol Trace Elem Res 142(2011) 67-76.

[14] J.V. Bockhaven, L.Spıchal, O. Novak, M. Strnad, T. Asano, S. Kikuchi, M. H€ofte and D.D.Vleesschauwer, Silicon induces resistance to the brown spot fungus Cochliobolus miyabeanus by preventing the pathogen from hijacking the rice ethylene pathway. New Phytologist 206 (2015) 761-773.

[15] J.F, Ma and N. Yamaji, A cooperative system of silicon transport in plants, Trends in Plant Science. 20(2015) 435-442.

[16] I.S.K. Pearce and R. Van der Wal, Interpreting nitrogen pollution thresholds for sensitive habitats: the importance of concentration versus dose. Environment Pollution 152(2008) 253-256.

[17] H.A. Currie and C.C. Perry, Silica in plants: biological, biochemical and chemical studies. Annals of Botany,100(2007) 1383-1389.

[18] J. Schaller, J. Schoelynck, E. Struyf and P. Meire, Silicon affects nutrient content and ratios of wetland plants, Silicon. 8(2016) 479-485.

[19] N.A. Sajedi, M.R. Ardakani, H. Madani, A. Naderi and M. Miransari, The effects of selenium and other micronutrients on the antioxidant activities and yield of corn (Zea mays L.) under drought stress. Physiol Mol Biol Plants. 17(2011) 215-222.

[20] M.M. Azevedo, A. Carvalho, C. Pascoal, F. Rodrigues and F. Cássio, Responses of antioxidant defenses to $\mathrm{Cu}$ and $\mathrm{Zn}$ stress in two aquatic fungi, Sci Total Environ. 377(2007)233-243.

[21] L. Bai, F. Sui, T. Ge, Z. Sun, Y. Lu and G. Zhou. Effect of soil drought stress on leaf water status, membrane permeability and enzymatic antioxidant system of maize. Pedosphere.16(2006) 326-332.

[22] Y. Nakano and K. Asada, Hydrogen peroxide scavenged by ascorbate specific peroxidase in spinach chloroplasts. Plant Cell Physiology. 22(1981) 867-880.

[23] X. Shen, X. Li, Z. Li, J. Li, L. Duan and A. E. Eneji, Growth, physiological attributes, and antioxidant enzyme activities in soybean seedlings treated with or without silicon under UV-B radiation stress. Journal of Agronomy and Crop Science 196(2010) 431-439.

[24] H.K. Lichtenthaler, Chlorophylls and carotenoids: pigments of photosynthetic biomembranes. Methods Enzymol. 148(1987) 350-382.

[25]K.G. Golezani and R. Lotfi, The impact of salicylic acid and silicon on chlorophyll a fluorescence in mung bean under salt stress. Russian Journal of Plant Physiology, 62(2015) 611-616. 
[26] H. Gong, X. Zhu, K. Chen, S.Wang and C. Zhang, Silicon alleviates oxidative damage of wheat plants in pots under drought, Plant Science. 169(2005) 313-321.

[27] S. Xu, J. Li, X. Zhang, H. Wei and L. Cui, Effects of heat acclimation pretreatment on changes of membranelipid peroxidation, antioxidant metabolites, and ultrastructure of chloroplasts in two cool-season turfgrass species under heat stress, Environ Exp Bot. 5(2006) 274-285.

[28] J.F. Ma and N. Yamaji, Silicon uptake and accumulation in higher plants, Trends in Plant Science 11(2006) 392-397

[29] J.F. Ma, K. Tamai, M. Ichii, G. Feng and A. Wu, Rice mutant defective in Si uptake, Plant Physiology. 130(2002) 2111-2117.

[30] R. Ahmad, S. Zaheer and S. Ismail, Role of silicon in salt tolerance of wheat, Plant Science. 85(1992) 43-50.

[31] J. Xue, J. Li, Y. Jin, D. Chen, H. Sun and C. Ji, Effect of silicon on Ryegrass growth and photosynthsis under composite subsalt stress, Northern Horticulture. 4(2013) 88-91.

[32] Z. Zhu, G.Wei, J. Li, Q. Qian and J. Yu, Silicon alleviates salt stress and increases antioxidant enzymes activity in leaves of salt-stressed cucumber (Cucumis sativus L.), Plant Science. 167(2004) 527-533. 